\title{
The Challenges and Prospects for Regional and Economic Integration in West Africa
}

\author{
Maiyaki Theodore Bala ${ }^{1}$ \\ ${ }^{1}$ Department of Private Law, Faculty of Law, University of Abuja, Gwagwalada, Nigeria \\ Correspondence: Maiyaki Theodore Bala, Senior Lecturer, Department of Private Law, Faculty of Law, \\ University of Abuja, Gwagwalada, Nigeria. E-mail: theodoremaiyaki@gmail.com
}

Received: January 18, 2017

Accepted: March 13, 2017 Online Published: April 19, 2017

doi:10.5539/ass.v13n5p24

URL: https://doi.org/10.5539/ass.v13n5p24

\begin{abstract}
The age-long practice of the individual survival of nations have long given way to the emergent concept of integration and cooperation among states as an option to meeting the collective development needs of the cooperating states. Practice has shown over time that when states take comparative advantage of each other's strength and weaknesses, it opens the space and engenders the potentials for specialization, development of the economies of scale and indeed reduces the cost of production. Consequently, it enhances the purchasing power of the citizenry. In recent times, there have been significant increases in the efforts of developing countries especially in Sub-Saharan Africa to achieve regional economic integration. The advent of the African Union (AU) and the New Partnership for Africa's Development (NEPAD) have given new impetus to the global African and regional integration processes and has focused particular attention on the need to take decisive action to tackle the continent's numerous problems through the instrument of the economic integration strategy. This paper appreciates the evolution of regional integration and analyses the rationale for economic integration in West Africa. It evaluates the challenges and prospects of integration in West Africa.
\end{abstract}

\section{Introduction}

Regional integration as a strategy of the collective economic survival of nations around the world has gained prominence in recent times. It has given nations the options of cooperation and competition. It has provided for participating states the options of promoting the best areas of specialization whilst at the same time ceding to other participating nations products considered to be within the purview of the strength of those other states. The most attractive factor of integration is chronicled on the general principle of the creation of a common market where goods, services and capital are guaranteed freedom of movement unhindered within the integrated area. This guarantee includes the right of residence and establishment. In the sub Saharan African regions, we have seen the revitalization or the expansion of existing regional economic arrangements and the formation of new groupings. The foregoing initiatives have interestingly coincided with the current developments in the Western and industrialized world who have since taken up the instrument of economic integration as a vehicle to political and socio-economic prosperity. Regional economic integration is increasingly recognized as the viable space within which small and developing economies can better organize themselves to survive economically and politically in a highly competitive world.

The Economic integration strategy in West Africa is fashioned along the lines of the European Union. The Treaty of ECOWAS reveals a compendium so similar the E U Treaty in so many respects. Since we are living in a global village with closely knit ties and economic engagements across different borders, it follows therefore that the factors that affect the integration process in the European Union has great potentials of spilling over to the other economies and more particularly West Africa, with its nascent and undeveloped integration experiment. This article shall seek to evaluate and elicit those factors that have challenged the development of the ECOWAS experiment in attaining the desired goals of economic integration and further espouse the potential gains of moving on with the strategy as an antidote to the current unacceptable and intolerable economic conditions in the sub region. The paper shall further interrogate by way of comparative evaluation the impact of the current crisis in the EU showing whether or not the west African experiment can be insulated from the vagaries of this crisis, since the later was fashioned along the lines of the former and bring to the fore what lessons that are to be learnt therefrom. 


\section{General Overview}

It must be noted that the West African Sub-region Currently operates two currency regimes with the Francophone Countries of Benin, Burkina Faso, Cote D'lvoire, Guinea Bissau, Mali, Niger, Togo and Senegal already formed into the common currency of the CFA Franc under the control of the West African Economic and Monetary Union (WAEMU) Central Bank (Saleh Nsouli, 2000) On the other hand are the countries of Gambia, Ghana, Guinea, Nigeria and Sierra Leone, which operate their individual national currencies. In the year 2000, these Anglophone countries, in response to the CFA Franc formed a second monetary zone (WAMZ) with a view to harmonizing their monetary and economic policies towards forming a common monetary union and currency to be called the Eco (Nnanna Joseph, 2000). It is expected that it would then be easier for the two currencies of Eco and the CFA Franc to merge in the long run into a single West African ECOWAS currency. This second set of countries desire to converge under what is referred to as the second West Africa Monetary Zone (WAMZ) with the sole objective of establishing a common union to be characterized by a common Central Bank and a unified currency to be called the Eco in replacement of the current 5 existing national currencies.

Furthermore, as a foundation to the creation of a new Central Bank for the WAMZ which would be charged with the duties of currency and fiscal measures among the 5 countries in the second monetary zone, the West African Monetary Institute (WAMI) was formed as a precursor to the Common West African Central Bank (WACB) which has all the transition and implementation mandates as outlined. Due mainly to the inability of member countries to attain most of the convergence criteria, despite the earlier postponements, the second monetary zone which was scheduled to have taken off on the $1^{\text {st }}$ day of December, 2009 was shifted to the $1^{\text {st }}$ day of January $2015^{1}$, and now $2020 .^{2}$ The new date became necessary as an antidote to the activation and acceleration of all actions geared towards the realization of the emergence of the Eco to pave way ultimately for the West African common currency. Following the disturbing inability to meet with these datelines and the current struggles by the Countries of the WAMZ to meet with the criteria, Dr. Maiyaki opined that:

For WAMI to propel its role in the economic integration process being a convergence precondition itself, WAMI must undertake a self introspection, reviewing its capacity and organs, with a view to eliciting its area of weakness and making out to strengthen same considering that the new date for the takeoff of the Eco currency (2015) is just but around the corner. ${ }^{3}$

With the several regional integration in Europe, efforts have effectively promoted intergovernmental cooperation and whittle down the possibility of regional conflicts over the years. Other initiatives have also taken out barriers to free trade in the European regions, and boost the free movement of people, labor, goods, and capital across national borders. ${ }^{4}$ However, the sovereign-debt crisis, which began in 2009 following the financial crisis of 2008, has made countries in the eurozone, take austerity measures to stave off complete financial collapse, but the crisis is by no means over (Mount, 2012). Global economic, in the past couple of years of upheaval have sore tested the EU's Economic and Monetary Union (EMU) and its crowning achievement, the euro. The Eurozone crisis reveals the challenges of the EU's sui generis political status is no longer a mere collection of nation-states, yet not a fully fledged federal entity. (McNamara, 2010). Then, what is the expected future of European integration? What does the unfolding Eurozone crisis mean for the larger geopolitical position of the European Union in the light of the recent vote to exit Britain from the union? Nevertheless, it is possible to sketch out some significant milestones and signposts that will determine the path of Europe's future.

The critical question is whether the leaders and citizens of Europe are willing to upgrade their political institutions and equip them with the mechanisms to ease such political, financial and economic crises in the future. The way these issues are resolved or otherwise will fundamentally shape the broader political future of European integration $^{5}$ and its consequent impact on the West African experiment which is to a large extent its replica.

\section{Historical Evolution of Regional Integration}

The evolution of modern regional integration could be traced to Adolf Hitler of Germany who was the main catalyst of the European Community, although none of its leaders would readily admit him as a founding father.

\footnotetext{
${ }^{1}$ West African Monetary Zone. www.wami.imao.org 23/08/2009.

2 West Africa: 'ECOWAS single Currency Operational by 2020'. Cameroon-Tribune.cm 01/04/2016

${ }^{3}$ Maiyaki T.B: A handbook on the ECOWAS Treaty and Financial Institutions. 2012. Author house Publishers. Pg. 106

6. en.wikipedia.org/wiki/European integration. See also Ben Rosamond, Theories of European Integration, Palgrave 7. Macmillan, 2000, p.

21-22.

${ }^{5 .}$ Ibid
} 
Like Charlemange and Napoleon before him, Hitler brought together, by the sword, virtually the entire land area of the original EEC, destroying in the process the self-confidence of the nation states from which it sprang. ${ }^{6}$ These were recreated in 1945, but no longer saw themselves as autonomous actors on the world stage. The governments of the three smallest states; the Netherlands, Belgium and Luxemburg, decided in 1944, before the liberation of their territories had been completed, that their economic futures were inextricably intertwined. ${ }^{7}$ The Benelux Union came into force on January $1^{\text {st }}, 1948$ as a customs union, with the intention of progressing to a full economic union at a later stage. ${ }^{8}$

The United States and the Soviet Union each gave the nations of Western Europe a strong shove in the direction of unity, one with apparently benign, the other with malign intentions. The Organization for European Economic Cooperation (OEEC) was set up in 1947 in order to divide up among the member states the flow of the US aid under the Marshall Plan. ${ }^{9}$ The aid program was completed over three years, but the OEEC continued as a forum for promoting economic cooperation and free trade among Western European countries.

It is a truism to say, if the United States, partly no doubt through self-interest, had contributed hope, the Soviet Union on the other hand, contributed fear. Its brutal suppression of the countries of Eastern Europe, culminating in the communist takeover of Czechoslovakia in February 1948, forced several West European countries to come together for self preservation. ${ }^{10}$ As early as March 17, 1948 the treaty of Brussels was signed, providing for a 50 years agreement between the United Kingdom, France, Belgium, the Netherlands and Luxemburg known as the Western European Union. This provided for collaboration in economic, socio-cultural matters and collective self-defense. In practice the Western European Union became largely superseded by the creation of NATO in 1949, although it remained in existence and its five members were joined by West Germany and Italy in $1954 .{ }^{11}$

After the Second World War, European Coal and Steel Community (ECSC) was formally established by the treaty of Paris, signed in April 1951 and was placed under a single high authority which was to supervise its development. By 1952 the six governments of France, West Germany, Italy, Belgium, the Netherlands and Luxemburg signed a treaty in May, providing for the creation of a European Defence Community (EDC). Considering the low level of acceptance and progress achieved by these preceding organizations, and in view of the believe that the path towards European Unity lay through Economic rather than military cooperation, the treaty of Rome was signed in 1957 establishing the European Economic Community (EEC). ${ }^{12}$ This was to transmit into the European community (EC) as an amalgamation of the EDC and ECSC.

In recent years, regional integration has become the focus of intense global interest and debate. Regional integration has been a recognizable feature of international trade relations in the post-war period, though its salience has waxed and waned. Two waves of regionalism can be identified and a third may be underway. The first started with the establishment in 1957 of the forerunner to the European Union and, in the developing world, the adoption in Latin America and Africa of import-substitution regional integration schemes as the means to effect inward-looking growth. Most of the developing-country schemes initiated at this time eventually became moribund or collapsed, while the growing momentum of multilateral liberalization in the 1970s and 1980s contributed to the decline in the importance attached to regionalism.

A second wave of regional integration started during the second half of the 1980s. The origin of the "new regionalism' has been attributed to the drawn out nature and slow progress of the General Agreement on Tariffs and Trade (GATT) Uruguay Round negotiations, to the apparent success and fears aroused by the European Union's (EU) initiative aimed at establishing a Single European Market, the conversion of the United States to regionalism with its negotiation of the North American Free Trade Agreement (NAFTA) and its Enterprise for the Americas initiative that has led to proposals for a Free Trade Area of the Americas (FTAA). ${ }^{13}$

In the wake of political change (the Central American Common Market and the Andean Pact) Latin America, new life was breathed into some old integration arrangements, sometimes. In Asia, ASEAN initiated plans for an ASEAN Free Trade Area (AFTA), the South Asian Association for Regional Cooperation agreed in 1997 to

\footnotetext{
${ }^{6}$ Leonard D. Op.cit

${ }^{7}$ Ibid.

${ }^{8}$ Ibid

${ }^{9}$ Ibid.

${ }^{10}$ Ibid.

${ }^{11}$ Ibid.

${ }^{12}$ Ibid.

${ }^{13}$ Goldstein, op. cit. p. 456
} 
transform itself into the South Asian Free Trade Area while the Asia Pacific Economic Cooperation (APEC) also committed to trade liberalization objectives on a non-preferential basis. ${ }^{14}$ In Africa, initiatives have included the revitalization of existing regional groupings, the creation of new groupings and the notification of ambitious targets at the $36^{\text {th }}$ OAU Summit in Lomé, Togo in July 2000 to propel the formation of an African economic and political union. (Mkwezalamba Maxwell \& Chinyama Emmanuel, 2007)

Some observers believe that a third wave of integration is currently underway (Peter, 2002). While there were 125 Regional Trade Agreement (RTAs) notified during the GATT years, a further 125 new RTAs have been notified since the establishment of the World Trade Organization (WTO) on 1 January 1995 up to April $2002 .{ }^{15}$ This represents an average of 15 notifications every year to the WTO, compared with an annual average of less than three during the four and a half decades of the GATT. ${ }^{16}$ On average, each WTO Member is involved in five RTAs, though some are parties to ten or more. According to a recent WTO study, most developing countries now participate in RTAs. Of the 243 RTAs estimated to be in force in April 2002, between 30-40 per cent are agreements concluded between developing countries. ${ }^{17}$

\section{Rationale for West African Economic Integration}

The ultimate goal of any economic integration arrangement is the formation of a unified economic space among the participating countries. Monetary and economic integration may evolve from trade links, as well as, historical and cultural ties. The process entails the harmonization of macroeconomic policies, legal frameworks and institutional architectures, towards nominal and real convergence.

From the post-independence era, the necessity for West African integration has been imperative and central to the political and economic vision of the sub regional leadership. The fragmentation of the continent into small nation states with scant economic coherence drove the leadership of the sub region to consider economic integration as a central element of their development strategy. The forces and challenges of globalization have brought this imperative ever more sharply into focus as nations including the prosperous ones are constantly engaged in constant and fierce competition for the world's scarce resources with the consequence that the weaker nations of the world continue to confront un warranted relegation and dereliction. It is interesting that even the so-called advanced countries rely on the strategy of integration to bolster their positions in this competition.

\section{The Challenges of Economic Integration in West Africa}

There are marked differences in development between the Fifteen ECOWAS countries. There are also three different groups with regard to the implementation and time-scale for lifting custom barriers. The first group comprises the richest and most industrialized countries, e.g., Nigeria, Ivory Coast, Ghana and Senegal. The second group comprises the other eleven countries. However, an intermediate group has been identified comprising Guinea-Conakry, Sierra Leone, Liberia, Togo and Benin.

According to the Revised ECOWAS treaty, "the aim of the community is to promote co-operation and development in all fields of economic activity, the purpose of which is to increase the standard of living of its people, to enhance and maintain economic stability, to strengthen relations between its members and to


monetary union on the member states, but rather it provides for harmonization of monetary policy, which is needed to ensure that the community functions smoothly. A West African Clearing House (WACH) was set up in 1975 which was transformed into abroad based autonomous specialized agency of the ECOWAS called the West African Monetary Agency (WAMA) in 1996 by the central banks of the ECOWAS States to achieve this purpose. Likewise a cooperation, compensation and development fund was provided for, with the aim of providing an even distribution of the costs and advantages of integration between the different member states of the community.

Nevertheless, many reports and studies on ECOWAS confirm the inefficiency of this organization. Therefore, "with no political resources and only limited financial resources, the wish to tackle everything only means that

\footnotetext{
${ }^{14}$ Ibid

${ }^{15}$ WTO 2002. Regional Trade Integration under Transformation, Paper presented to the Seminar on Regionalism and the WTO, 26 April 2002.

${ }^{16}$ The WTO figures only include notified agreements, and there are many other non-notified, or not yet notified, agreements in existence. Also, non-reciprocal preferential agreements covered by waivers are not included in these numbers

${ }^{17}$ WTO 2002 Op Cit p. 24

${ }^{18}$ Art.2. of Revised ECOWAS Treaty Op. cit
} 
nothing is done. ${ }^{, 19}$ For its part, the African Development Bank (AFDB) states in its report on the problems of integration in Africa, that the "implementation of a system of cooperation and the achievements of ECOWAS have been relatively insubstantial. Trade within the community has not been stimulated; it has even shown a tendency to decrease" 20

The obstacles to greater progress in regional integration within ECOWAS are evident. Difficulties of an economic nature, such as obstacles to intensifying trade and monetary problems; and those of a political nature, showing the weakness and even the lack of political will of member states. In spite of the fact that there are over twenty multilateral cooperation schemes and sub-groupings in West Africa (excluding various bilateral arrangements between West African States), and the obvious advantages derivable from economic cooperation among member States, the problems, challenges and impediments to the realization of the ECOWAS objectives continue to come to limelight. Among these challenges are:

- The lack of adequate infrastructure by way of roads, energy, power, rail, telecommunications and other links for the facilitation of the free movement of goods, capital, services and persons, including the right of residence poses a major challenge to the consummation of the integration dream in the West African sub region. This situation is mainly due to the incidences of weak productive and industrial sectors in most of the member states, arising largely from poor and decaying infrastructural conditions. Economic integration is an aggregate of the desire of nation-states to garner their resources together for the purposes of gaining comparative advantages within the region. However, the greater challenge here is that of a region so bereft of infrastructure as a pre requisite for the establishment of a relationship with another country.

- There is no gainsaying that the lack of a defined role for financial institutions in the legal framework in the West African integration scheme has remained at the heart of the reasons why the so much and so long awaited integration of the states of west Africa still remains a mirage. An evaluation of the treaty reveals a clear dearth of the provisions necessary to define and accord the respective financial institutions specific roles and parameters enough to accord them the formal intervention edge needed to facilitate the indispensable provision of funds and policy to finance and control the ambits of the integration scheme to its desired destination. This development has been largely responsible for the complacency that has been exhibited by the financial institutions in dealing with the issues of integration. As it stands today, the financial institutions take indiscriminate and unharmonized approaches in dealing with the issues of integration.

Coextensive to the foregoing is the challenge faced by the financial institutions in the non-implementation of a system of cooperation among ECOWAS member countries. One of such system of cooperation is in the area of a common customs and monetary union, which will enable the sub-region to widen its market area and also help in boosting a strong common currency. This has not been achieved and up to date, each member country of the sub-region still uses its own customs tariff as it is evident at the borders. Thus, trade within the community has not been stimulated ${ }^{21}$, and the way it goes, it has even shown a tendency to decrease. As trade decreases, so does the potential of the financial institutions to find fertile cooperative grounds of engagement.

It is further observed that in the realization of their mandate in the economic integration of West Africa, financial institutions are constrained by the non-realization of a common Central Bank for ECOWAS. It is a known fact that the countries of Europe were able to achieve a common currency with ease because of the crucial and pivotal role played by the European Central Bank (ECB) in the areas of monetary and economic policy coordination. The WAEMU countries were also able to achieve their current tempo of macroeconomic stability because of the sustained intermediation role played by the common Central Bank of West Africa States (BCEAO), which was established by the francophone countries of the sub-region. But under ECOWAS experiment, the establishment of the ECOWAS Central Bank still exists in form not in reality; the mechanisms needed to achieve this are weak and the governments are not pro-active in this regard.

- The absence of a common language among the states of the West African sub-region constitutes a linguistic complexity and engenders a multiplicity of institutions, some of which are exclusive to the language group. Although not exclusive, it would have been desirable to have a common language platform within the region to ease the communication and advocacy barrier. Language in West Africa also has had the unfortunate potential to divide the people who see each other as different and immutable. The Economic Integration project prospects to bring different people together as one with a view to taking comparative advantage of each other's relative strength

\footnotetext{
${ }^{19}$ Tuho C.V Op. cit

${ }^{20}$ Ibid

${ }^{21}$ West Africa and the Future of Relations between the ACP countries and the EU. @ www.euforic.org/fes/3gb-tuh.htm, Web 20/04/2004
} 
and weaknesses. Clearly the attitude of the people of this region to the linguistic differences has rather been counter productive. Of even greater concern is the sharp divide along the colonial languages of English and French. The influences of these two languages and the associated colonial masters have been that of competition as opposed to cooperation towards the attainment of economic emancipation of the sub region.

- Bad governance and Political instability have plagued many of the ECOWAS countries and also the insufficient political will exhibited by the leadership of some member states. After over 40 years, the integration project is still at infancy. No country in the sub region has shown leadership and each continues to view the other with suspicion. Considering that integration involves the cession of a measure of sovereignty, there's no gainsaying that the clear and unfettered commitment of member states beyond lip service and signing treaties or protocols is a sine qua non for the emergence of a true integration experiment in the sub region. The sit-tight approach of our leaders towards sovereignty is deplorable and their continued refusal to 'give a bit to gain so much' is also despicable. It is desirable that nations of the sub region develop a new genre toward this untapped strategy and it is even more incumbent upon the bigger nations in the sub region like Nigeria to step forward and provide leadership, otherwise the entire project would remain a mirage.

- The persistence of colonial ties, diverse and distinct administrative systems, including the persistence of both local and foreign interests in the preservation of the status quo has remained a major inhibition towards attainment of the West African Economic Integration dream. The interference in the socio political lives of the West African countries by the former colonial metro poles in pursuing and sustaining the preservation of Africa's dependence on European practices and accoutrements of international relations pose a major challenge. Any attempt at sub-regional grouping tends to elicit some reaction from former colonial governments who would offer inducements and/or threats to prevent would-be members from adhering to agreements. To this effect, each actor perceives the threat or inducements as more beneficial than the cost or benefit of adhering to regional agreements. $^{22}$

- The existence of different tariff arrangements with differing rates of customs duties and the over-dependence on revenue from import duties by many West African countries presents yet a major challenge to the integration arrangement. This is evident in the fact that tariffs representing one of the major ambits of integration are yet very discriminatory and therefore inspiring no confidence amongst the member states.

- The existence of different currencies (some of which are not easily convertible), present yet another challenge in the integration strategy. It is true that the concept of monetary integration grows faster and provides an expedient implementation platform where the integrating countries agree to converge into the same currency, as that would pave the way for the facilitation of convertibility, unrestricted movement of people, goods and services and indeed the payment of customs duties. Thus the continued use of respective currencies by the member states creates the problems of payments arrangements and convertibility with consequent difficulties for inter-state commercial transactions. This stunted situation no doubt elongates the destination of economic integration in West Africa.

- Another major challenge is the incessant conflicts, wars and unbridled violence, which has weakened the sub-region's capacity for survival. The Sierra Leone Civil War, the Liberian conflict, the unconstitutional takeover in Niger Republic and very recently the potential election crisis looming in the Gambia are cases in point. The preponderance of such bitter conflicts in West Africa has ensured that famine, drought, destruction, refugee problems, diseases, etc, are common features of the socioeconomic landscape. The conflict situation in Africa exacerbated poverty across the continent and made it difficult to accelerate sustainable economic growth and development and destroyed physical infrastructure and human capital. Furthermore, conflicts in the sub-region have diminished the capacity of the state, the region and the continent to focus on integration and development, and adversely affected the prospects for achieving the MDGs (Eleazu, 1978). Thus the humongous untapped capital that was supposed to be used for integration purposes is in the long run channeled to reconstruction in these war-torn and drought ravaged countries. This makes it difficult for states to concentrate and integrate.

- The unexpressed fear of domination by the so-called bigger countries is another major challenge to the realization of the integration dream; Nigeria overshadows every other country in terms of population, gross domestic product, industrialization and natural resource endowment in the region. The argument is that Nigeria would potentially be the most dominant country in the market and will benefit more in the integration strategy than any other country in the sub-region. The French tends to provoke this fear of domination as they strive to maintain their sphere of influence in the sub-region. ${ }^{23}$

\footnotetext{
${ }^{22}$ Vuho C.V Op. cit

${ }^{23}$ Vuho C.V Op. cit
} 
- The inability of ECOWAS to provide an organized adequate market for the greater part of the commodities produced within the sub-region has also posed a major challenge given the fact that member countries do not support or patronize one another to boost trade in goods and services as most of the goods that are produced by member countries are still imported from outside the sub-region. This has facilitated the dependence of member countries on the outside markets.

- Another challenge is the attitudinal, ideological and psychological makeup of the leaders of the Member States of ECOWAS towards national sovereignty. Most states being newly independent, held a strong determination to demonstrate and maintain their national sovereignty and integrity vis-à-vis other African States. This tenacious hold on sovereignty led to the adoption of national currencies, national central banks, national airways, national shipping lines, national stock exchanges, etc. In as much as these were thought to be the outward manifestations of nationhood and sovereignty, they became symbols of attachment, eliciting loyalties that could not transcend the national borders. ${ }^{24}$

- The situation of debt in Africa is also a major concern to African leaders. The impact of the debt crisis and the externally imposed Structural Adjustment Programs (SAP) on Africa mars the capacity for economic integration. As a result of the debt problem, underdevelopment seems to have assumed a frightening proportion on the region (Fawole, 1992). Outstanding total debt stock at the end of 2004 was estimated at $\$ 330$ billion in nominal terms and African countries continue to pay over $\$ 30$ million a day on loans contracted over the last 30 years. $^{25}$ Thus, $^{2}$ African countries are spending their scarce resources on servicing debts instead of allocating them to growth and the social sectors. The reality now is that even if domestic macro-economic mismanagement and political instabilities alone do not obstruct the realization of economic integration, it is expected that the daunting problems of external debt and the attendant IMF-imposed SAP packages will be enough to wreak incalculable havoc on the already prostrate economies of West Africa, thereby preventing the achievement of both regional and economic development in Africa.

- Another challenge is that often times, member countries fail to involve the civil society, the private sector and mass movements in the process of integration and this propels the defective nature of the integration machinery. No proper enlightenment is given to the citizens of the community as regards the goals of the community, and no form of encouragement is offered from the governments of states to the civil society and private sector of the community for a proper understanding and better collaboration between them in order to ensure that the objectives of the community are met.

Thus as examined above, the limitations to West Africa development are basically due to cultural, economic and social-political problems, and this has been the major difficulty posed in the realization of regional cooperation and integration.

\section{The Prospects and Strategic Visions for Integration in West Africa}

It is observed that the current instability in Africa's political, economic decline, and social discontent reflect a leadership crisis on the continent. If this is true of individual countries, it is equally valid for the regional integration process. The emergence of stronger leadership could supply the vision and necessary direction and demonstrate the sacrifice and commitments that are essential in any cooperative endeavor. However, not all countries are given the same appreciation of the need for cooperation. It would appear that some have to be coaxed, persuaded and pulled along by others.

The advantages to be derived from West African economic cooperation are so obvious and the role that economic cooperation could play in the development of each African country is so fundamental that one is at a loss as to why a solution to the problems has not been the main concern of member states of ECOWAS. Indeed, advocates of closer economic integration in the sub-region have ably demonstrated that the "critical factors on which the arguments and conclusion against ECOWAS are based on some of the very factors which the West African countries are desirous of changing through economic integration."26

West Africa has been fortunate in having certain leaders and countries that are strongly committed to the ideal of regional integration. Some member states have always been more assiduous in meeting their financial obligations to the community than others and the committed ones have taken the lead in initiating important regional cooperation projects and programs. Some community arrangements have required special sacrifices from certain member states (regarding formulas for determining financial contributions, trade liberalization

\footnotetext{
${ }^{24}$ Eleazu, U.O. Op. cit

${ }^{25}$ Mkwezalamba and Chinyama, Op.Cit p. 5

${ }^{26}$ Adeniyi, E.O. Op.cit, p.613
} 
schedules, or compensation formulas for the loss of tariff revenue), and the acceptance of these arrangements is a clear manifestation of solidarity and community spirit. ${ }^{27}$ Some commentators have argued that West Africa's low economic development and the indifference of some governments to regional integration under ECOWAS make it necessary for West Africa to adopt a loose form of regional cooperation conducted on a pragmatic and ad hoc basis. The successes of the Southern African Development community (SADC) and the Association of South East Asian Nations (ASEAN), and the loose arrangement with the Latin American Economic System (SELA) have been cited to support this argument. ${ }^{28}$

An analysis of the West African experience of integration within the context of ECOWAS shows an abysmal record with regard to the poor execution of the community programs. The provisions of the revised treaty instituting the principle of supra-nationality are not being applied. Several protocols are contravened, particularly those pertaining to the free movement of goods and persons. The situation shows all too clearly that a sense of belonging to a plural-national community is critically lacking.

The extent to which ECOWAS programs succeed and the materialization of the political commitment of member states will depend on how effective the Executive Secretariat proves to be at promoting the development of West Africa. This basic principle brings to the fore the need for coherent community programs and policies that are realistic, pragmatic and capable of furthering the cause of regional integration. To that end, it will be necessary to formulate programs that emphasize the benefits of collective action. The Executive Secretary will need to pinpoint priority areas of intervention within which actions will be undertaken in tandem with efforts being made by individual states.

If on the whole, the results of the integration efforts made in West Africa by ECOWAS have, as already indicated, been clearly below expectations, there are, to some extent, promising signs which indicate better prospects for the future of ECOWAS. Some of these signs are the "recent events in the political and economic scene of West Africa, which have gradually helped to remove the principal obstacles to integration." ${ }^{29}$ Among these are:

- The advent of democracy in most ECOWAS countries, particularly in Nigeria, which is the dominant economy in West Africa;

- The gradual withdrawal of the state from the sectors of productive activity, and the realization that the private sector must be the mainstay of growth and economic integration;

- The adoption of a strategy for accelerating the ECOWAS process of integration in order to create a single regional market based on trade liberalization, to establish a common external tariff and harmonized economic and financial policies.

- The harmonization of the programs of ECOWAS and WAEMU in connection with the acceleration of the process of integration in West Africa;

- The restructuring of the Executive Secretariat and the ECOWAS Fund with the frame-work of the improvement of their operational procedures. ${ }^{30}$

- With the adoption of the African Economic Commission (AEC) treaty and the revision of the ECOWAS treaty, West Africa seems to possess the institutional framework necessary to move forward on regional integration, the future course and success of that process cannot be taken for granted.

- Monetary integration is also needed in order to harmonize monetary policies, improve macro-economic management, and eventually replace the weak inconvertible domestic currencies of the region with a single regional currency. ${ }^{31}$

- Regional integration should also embrace cooperation in the social, cultural defense, and political fields, because the absence of stable and compatible policies in these areas militates against the success of regional integration in other respects. Developments in the EU amply demonstrate the need for serious consideration of these other dimensions of regional integration.

\section{Conclusion}

As part of the ECOWAS strategy, the States through the treaty have the hydra-headed, multidimensional strategy

\footnotetext{
${ }^{27}$ Bundu Abbas. "Strategic Vision and Prospects: ECOWAS and the Future of Regional Integration in Africa" @ http//www.idrc.ca/lacro/ev. $23 / 06 / 2005$

${ }^{28}$ Ibid

29 “Discover ECOWAS”@ http//www.ecowasachiv.htm. 23/08/2010

${ }^{30}$ Ibid

${ }^{31}$ Bundu, A. op.cit
} 
of integration set down by the Economic Community of West African States in areas of potential cooperation between themselves. This strategy when pursued to the later would ultimately serve as the fulcrum of their activities for success. These areas appear to have covered predominantly the totality of the most strategic national human endeavor desirable under any economic integration agenda, thereby setting a development index or barometer for the West African sub-region. Undoubtedly, the successes that will be recorded in these areas would sign post the attainment of the set development objectives of the West African sub-region.

However, in the wake of the global economic meltdown of 2008, the EU has been struggling with a slow-moving but unshakable crisis that has underscored the flaws behind their common currency, the euro. Today, the European debt crisis is an ongoing financial crisis that has made it difficult for some countries in the eurozone to refinance their government's debt without the assistance of third parties. Notwithstanding the austerity measures taken to stave off complete financial collapse in the eurozone, the crisis is by no means over.

Clearly, there is no gainsaying that with the fierce competition among nations to optimize their market advantages above others with the strategy of integration leaves the nations of West Africa with little or no option but to cue in. These nations must embrace this option wholeheartedly and with unbridled commitment, especially in view of the fact that even the successful nations of the world which would have otherwise been complacent, are embracing the strategy to sharpen their advantages over and above their competitors. For Africa, and particularly West Africa to catch up with this race, it would appear that their option to economic integration of the region is almost non-existent. It is even more worrisome considering the fact that the other international integration experiments are not only relying on their internal markets created through integration, but are also taking comparative advantage of the large and abundant markets that abound in West Africa to the detriment of the nations of West Africa. This debilitating and unacceptable status quo has technically destroyed the production and manufacturing base and potentials of the region, which in the long run has converted it to a consumption economy, dependent on the inflows from the markets that are already engulfed in the fierce competitions that have been engendered by the vehicle of integration from elsewhere.

It follows logically therefore that the ground is fertile and the prospects are unlimited for the urgent change of approach and attitude by the people, governments and countries of West Africa in adoption the strategy of economic integration as the panacea to the myriad of development and socio-economic challenges that have long bedeviled the region. ECOWAS and its institutions must be strongly positioned, funded and empowered to drive this process on a fast track towards achieving the region's development dream and pull its people out of squalor and want.

\section{References}

Abbas, B. (2005). Strategic Vision and Prospects: ECOWAS and the Future of Regional Integration in Africa.

Asante Samuel K. B. (1997). Regionalism and Africa's Development: Expectations, Realities and Challenges. Basingstoke: Macmillan Press. https://doi.org/10.1007/978-1-349-25779-9

Eleazu, U. O. (1978). Multinationals and Politics. In Readings and Documents on ECOWAS (1st ed.). Nigerian Institute of International Affairs, Lagos.

Fawole, A. (April/July 1992). IMF and the Africa Debt. Quartely Journal of Administration, 28(3/4), 11-36.

Garden, T. (2001). The Politics of Economic Integration in Europe. Indiana University.

Goldstein, J. S. (2001). International Relations (4th ed.). Washington, D. C: Longman Publishers.

McNamara, K. R. (2010). The Eurocrisis and the Uncertain Future of European Integration. Council of Foreign Relations Press.

Mkwezalamba Maxwell, M., \& Chinyama Emmanuel, J. (2007). Implementation of Africa's Integration and Development Agenda: Challenges and Prospects. African Integration Review, 1(1).

Mount, H. (2012). The Eurozone Crisis. Readers Digest, UK.

Nnanna Joseph, O. (2000). Monetary Integration in ECOWAS: The case of the West African Monetary Zone (WAMZ). In ECOWAS Milestones in Regional Integration. Lagos: Nigerian Institute of International Affairs.

Peter, L. (2002). New Bilateralism in the Asia-Pacific. The World Economy, 25(9), 1279-1296. https://doi.org/10.1111/1467-9701.00492

Praet, P. (2012). European Financial Integration in Times of Crisis. Milan: International Capital Market Association (ICMA). 
Rosamond, B. (2000). Theories of European Intergration. Palgrave Macmillan.

Saleh Nsouli, M. (2000). Capacity Building in Africa: The Role of International Financial Institutions. Finance and Development, 37(4). A quarterly Magazine of the IMF.

Van Ginkel, H., \& Van Langenhove, L. (2003). Introduction and Context. In H. van Ginkel, J. Court, \& L. Van Langenhove (Eds.), Integrating Africa: Perspectives on Regional Integration and Development. UNU Press.

Wallace, W. (2002). Regional Integration: The European Experience (2nd ed.). Oxford University Press.

\section{Copyrights}

Copyright for this article is retained by the author(s), with first publication rights granted to the journal.

This is an open-access article distributed under the terms and conditions of the Creative Commons Attribution license (http://creativecommons.org/licenses/by/4.0/). 